\title{
Students' Perception of the Implementation of Edmodo Learning Platform in Online Learning
}

\author{
Yanuar Dwi Prastyo ${ }^{1}$, Maratus Solihah ${ }^{2}$ \\ ${ }^{1}$ Universitas Bandar Lampung, Lampung, Indonesia, 35142 \\ ${ }^{2}$ Universitas Bandar Lampung, Lampung, Indonesia, 35142 \\ Corresponding Author: Yanuar Dwi Prastyo
}

\begin{abstract}
The purpose of this research is to explore the implementation of the Edmodo learning platform in online learning. This study was conducted to determine students' perceptions about the application of the Edmodo learning platform in online learning and the benefits of using Edmodo. This research used qualitative method. The population used in this study was 20 students. Purposive sampling was used in this study. Data was collected using questionnaires and interviews. Many applications are used in online learning, but students need applications that are comfortable to use while online when learning online. So that students don't feel bored when learning online, teachers must use several methods. Edmodo is often used to help do online learning because it can be done anywhere and anytime. The result of this study showed that implementation of Edmodo is very helpful for students in doing online learning, because Edmodo is easy to use. Combining the two instruments, the Edmodo application is able to facilitate them in online English classes. Most of the respondents agreed that Edmodo is used in online learning.
\end{abstract}

Keywords: Edmodo learning platform, online learning, online English classes

\section{INTRODUCTION}

The COVID-19 pandemic caused by a virus that started in Wuhan, China, in 2019. The COVID-19 pandemic has many impacts, starting with the economic and social sector, as well as the education system. Due to the Covid-19 outbreak, many employees in the economic sector were temporarily suspended or even terminated from working with companies. In addition, the company experiences a lot of uncertainty in the business economy, so the company has no choice but to temporarily lay off and lay off workers. Apart from the economic side, according to UNESCO in April 2020, in education 1.6 billion students were dismissed from schools and universities, this is one step to reduce the spread of Covid-19 (BBC, 2020). Approximately $90 \%$ of the total student population in the world, efforts to leave students off are not only giving them a day off, but changing the learning system which is usually done face-to-face and is now being done online. The Covid-19 pandemic was very influential in the world of education because during this Pandemic the learning process could no longer be done offline. Therefore, education is carried out online as a platform and becomes remote emergency teaching. Students use several technologies as learning tools. Online learning is carried out using the internet and several technologies that can develop material in online learning.

In technology education has a very important role, including technology as an offline or online learning medium. With technology students will have extensive knowledge and be able to find information that can be accessed free of charge. Technology is referred to as a learning tool that functions in the world of education 
(Miarso, 2007). Technology has been an integral part of human life in the modern world. Nowadays the use of technology is in demand by many people and makes technology an effective learning tool for students. The use of technology can also improve the quality of education and make students interested and enthusiastic about learning. The existence of technology has a big impact on the progress of education and the use of technology is an obligation in learning. Technology can increase student creativity with computerized development. Learning techniques can use android, laptops and so on.

Platform is the place used to run system software. Platform is programs that can support the success of online learning. There are several platforms that may be used in a online learning process, including Google Classroom, Edmodo, and others, Teacher's Room, Your School, Smart Class, Zenius, and Google Suite for Education (Mirzon Daheri, et all, 2020). In online learning, there are several online platforms that are usually used by lecturer some of which are Google Classroom, Zoom, Google Meet, Edmodo and so on. The choice of technology use is also very important so that the material presented by the lecturer can be easily understood. From some of these technologies, I am interested in Edmodo because the features in Edmodo are easy to use by students and not confusing. Edmodo has been used for blended learning in a variety of ways and has had a significant beneficial impact on the learning process (Alebaikan, 2010). Edmodo can be used in online learning because students can interact with lecturer and can increase students' social interaction. Students can express various ideas, and opinions, and create discussion forums. In Edmodo, students can see answers and scores directly and can easily communicate or share between users. In addition, students can communicate directly with text, images, sound, data and audio video through Edmodo and the resulting interactions can create an effective learning atmosphere.
Edmodo is an education platform that will connect lecturer and students or even parents to do online learning which can be accessed for free. Edmodo is a learning medium that has a positive role in discussions. Edmodo is a free social learning platform that allows lecturer and students to interact, communicate, and share educational materials and applications, as well as view assignments, grades, class discussions, and notifications. Its purpose is to assist educators in harnessing the potential of social media to help students learn more effectively individualize the classroom for each and every student (Giang \& Minh, 2014). The lecturer can assign assignments and assess students' work in Edmodo. It is intended that students would use Edmodo as an extension of face-to-face engagement, Can enhance their English skill in a set amount of time and it will boost their chances of getting a job, contact hours between students and instructors are increased, and peer feedback is made easier for pupils to establish a beneficial learning environment for them (Dewi, 2014). Edmodo provides code for the class subjects to be performed. This code is given to students by the lecturer to join the class. Edmodo can be accessed in a browser with the keyword www.edmodo.com or can download the Edmodo application.

\section{METHODOLOGY}

This study uses a qualitative research approach. I use qualitative research because this study explores how Edmodo is used, and researchers need information based on opinions rather than numbers that can be calculated by quantity. The population in this study was the third semester of the Public Administration Department in the Language Laboratory of the University of Bandar Lampung, amounting to 20 students. I used a purposive sampling technique to select the sample for this study. Because this study focuses on the use of Edmodo in the classroom and I only have access to major public administration 
in the third semester at the language laboratory, I employ purposive sampling.

In this study, I conducted online teaching using Edmodo three times to students in the language laboratory of the public administration faculty. After that, I gave the questionnaire link to the students. This questionnaire consists of 10 questions, 7 close-ended questionnaires and 3 openended questionnaires. This questionnaire was conducted to find out what they thought when learning online using Edmodo. After that, to complete the information, the researcher continued the interview to get more information from the students. Interviews are used to assist the data collection process. Researchers and respondents conducted interviews via chat via WhatsApp to obtain objective data. I interviewed 7 students to complete information about Edmodo implementation.

\section{RESULT}

The questionnaire was created to complete detailed information about students' perceptions of Edmodo application in online learning. This questionnaire consists of 10 questions based on indicators. The questionnaire was created using google form then sent online using WhatsApp and students can fill it out via android wherever and whenever. The following are the results of the questionnaire that the researchers got.

\subsection{The Strength of Edmodo}

In this study Edmodo has several strengths to implement online learning. These strengths are categorized into several indicators including usability, accessibility, helpfulness, and feature used.

\subsubsection{Usability}

Table 1 Students' Perception of Edmodo's Usability

\begin{tabular}{|l|l|l|l|}
\hline \multicolumn{1}{|l|}{$\begin{array}{l}\text { Question } \\
\text { Number }\end{array}$} & Statements & \multicolumn{2}{|l|}{ Responses } \\
\hline \multirow{2}{*}{$\begin{array}{l}\text { Your Experience Using } \\
\text { Edmodo }\end{array}$} & Helpful & $70 \%$ \\
\cline { 3 - 4 } & & Neutral & $25 \%$ \\
\cline { 3 - 4 } & & Unhelpful & $5 \%$ \\
\hline
\end{tabular}

In the table above, the researcher shows the results of students' experiences in online learning using Edmodo based on student perceptions. The table above shows that most students felt the use of Edmodo was very helpful in online learning. This is indicated by $70 \%$ of students having a good response to the experience of using Edmodo in online learning. This is supported by the results of student responses to open questions.

"Edmodo can help me understand learning materials, do and send assignments easily, and can see the grades given by the teacher"

(QOR2.9)

"Learning and also doing online assignments is easier using Edmodo"

(QOR1.9)

To strengthen the results of the experience using Edmodo, I conducted interview. Students also responded well to the use of Edmodo. All respondents I interviewed stated that Edmodo was very helpful. Learning and doing online assignments using Edmodo has also become easier. Data from interviews also provided a very helpful response to the use of Edmodo, because they felt Edmodo was very easy to use in online learning.

"Yes, I like it, because Edmodo is very easy to use and very easy to understand when using it"

(R2.B)

Then there are $25 \%$ of students who choose neutral because they cannot choose whether the experience of using Edmodo is helpful or not. $5 \%$ of students chose not to help, maybe because students felt unaccustomed to using Edmodo as an online learning tool. A total of 14 students, $70 \%$, had a good experience when using Edmodo. It can be concluded that the student experience of using Edmodo is very helpful, and very easy to use in online learning.

\subsubsection{Accessibility}

Table 2 Students' Perception of Edmodo's Accessibility

\begin{tabular}{|l|l|l|l|}
\hline Question Number & Statements & \multicolumn{2}{|l|}{ Responses } \\
\hline \multirow{2}{*}{3.} & \multirow{2}{*}{$\begin{array}{l}\text { Understanding the } \\
\text { features in Edmodo }\end{array}$} & Easy & $65 \%$ \\
\cline { 3 - 4 } & & Neutral & $30 \%$ \\
\cline { 3 - 4 } & Performing & Difficult & $5 \%$ \\
\hline \multirow{2}{*}{4.} & $\begin{array}{l}\text { assignments using } \\
\text { Edmodo }\end{array}$ & Helpful & $60 \%$ \\
\cline { 3 - 4 } & & Neutral & $35 \%$ \\
\cline { 3 - 4 } & & & \\
\hline
\end{tabular}


Table above shows questions about students' understanding of the features contained in Edmodo. Students find it very easy to understand the features contained in Edmodo. This was shown by $65 \%$ of students who responded well to Edmodo features. This is supported by the results of student responses to open questions.

"The features in Edmodo are easier to use and less complicated because after we collect assignments from teachers or lecturers, we can immediately give grades"

(QOR3.9)

"Edmodo makes it easier for lecturers and students to collect assignments"

(QOR9.9)

This was reinforced by student statements during the interview session. In the interview session, the respondent said :

"Like it, because the features of its use are not difficult, easy to understand, and quite clear"

(R4.B)

"...Edmodo makes it very easy for students to understand and answer about the material"

(R1.A)

$30 \%$ of respondents answered neutral because they could not make the decision to answer easily or not. 5\% of students answered difficult maybe because the features in Edmodo use English.

"The language setting can be changed to Indonesian, because not all students can understand English"

(QOR9.10)

So it can be concluded that even though one of the respondents found it difficult to use Edmodo because they used English, respondents gave results that on average respondents considered Edmodo's features to be easy to understand.

\subsubsection{Helpfullness}

Table 3 Students' Perception of Edmodo's Helpfullness

\begin{tabular}{|c|c|c|c|}
\hline Question Number & Statement & Response & \\
\hline \multirow{3}{*}{6.} & \multirow{3}{*}{$\begin{array}{l}\text { The contribution of } \\
\text { Edmodo learning to } \\
\text { English Skills. }\end{array}$} & Helpful & $60 \%$ \\
\hline & & Neutral & $30 \%$ \\
\hline & & Unhelpful & $10 \%$ \\
\hline \multirow{3}{*}{1.} & \multirow{3}{*}{$\begin{array}{l}\text { Using Edmodo in the } \\
\text { online learning } \\
\text { process }\end{array}$} & Helpful & $60 \%$ \\
\hline & & Neutral & $35 \%$ \\
\hline & & unhelpful & $5 \%$ \\
\hline
\end{tabular}

The results above show that according to students' perceptions, Edmodo's learning contribution is very helpful for English language skills. This can be seen from $60 \%$ respondents who answered that it is very helpful. It also supported by the results of the open-ended questionnaire. (QOR5.9)

"Learning English becomes easier"

$30 \%$ of respondents chose neutral because they could not provide a choice to help or not. $10 \%$ of students gave a statement that Edmodo cannot help in improving English skills. It can be because respondents do not really like learning English. Thus it can be indicated that more respondents felt very helpful. Therefore, the use of Edmodo can help improve students' English skills because most students answer this question very well.

The results from Table 3 can be concluded that $60 \%$ of students feel helped when using Edmodo in the online learning process. This can be seen from the results of the open-ended questionnaire.

"It is easier and faster to see the material and work on the questions"

(QOR4.9)

Students feel that using Edmodo in the online learning process is easier and less complicated when doing assignments. Respondents in the interview also stated,

"Edmodo makes learning easier in a pandemic like this"

(R7.A)

"Edmodo is also easy to use, apart from using a laptop / pc, Edmodo can also be accessed via cellphone, so I think Edmodo is a good application, and very useful to use nowadays"

(R2.A)

Students feel very helpful because Edmodo can be accessed using Android and can carry out assignments anywhere while there is still an internet connection. 35\% of students chose neutral because they could not choose the answer to help or not. 5\% of students choose not to help maybe they feel that Edmodo is boring and unhelpful in the 
online learning process. From the conclusion above, it can be indicated that more students gave good responses. Therefore, using Edmodo in the online learning process is very helpful.

\subsubsection{Future Use}

Table 4 Students' Perception of Edmodo's Future Use

\begin{tabular}{|l|l|l|l|}
\hline Question & \multirow{2}{*}{$\begin{array}{l}\text { Number } \\
\text { Statements }\end{array}$} & \multicolumn{2}{|l|}{ Responses } \\
\hline \multirow{2}{*}{5.} & \multirow{2}{*}{$\begin{array}{l}\text { Using Edmodo as a medium } \\
\text { for learning in the future. }\end{array}$} & Agree & $60 \%$ \\
\cline { 3 - 4 } & & Deutral & $35 \%$ \\
\hline
\end{tabular}

In the table above, respondents showed good results, $60 \%$ of students chose to strongly agree if Edmodo was used as a learning media in the future. This can be seen in an open-ended questionnaire.

"..... Edmodo is also good to use as a learning media in the future"

(QOR20.9)

The results of the interview can also strengthen this statement.

"Edmodo makes teaching and learning easier and doing assignments, as well as being able to ask questions easily. Therefore, it is good if it is used in the future"

(R5.E)

Students feel that using Edmodo is very helpful and very easy, therefore it is good to use for the future. There are 7 (35\%) respondents who chose neutral because they did not know whether to agree or disagree. Then $5 \%$ of students think they disagree if Edmodo is used in the future maybe because the respondent feels Edmodo is too simple because he cannot meet face to face. Thus, it can be indicated that more students who answered strongly agree if Edmodo is used as a learning medium in the future. It can be concluded that Edmodo is good if it is used as a learning medium in the future.

\section{The weaknesses of Edmodo}

From the results obtained by the researcher, in open-ended questionnaires and interviews, there are several weaknesses that have been raised by respondents.

\subsubsection{Internet Connection}

Most of the students think that the weakness of using Edmodo is on the internet connection.

"If for problems, only on the signal because opening the application must use the internet network, sometimes it is difficult to signal at home"

(R3.D)

This is a big problem found in respondents' statements regarding Edmodo use. In the open-ended questionnaire, respondents gave a statement about the obstacles in using Edmodo.

$$
\text { "...difficult network" }
$$

\section{(QOR11.8)}

This was also supported by several respondents during the interview.

"The problem of using Edmodo is the ineffective network"

\section{(R1.D)}

It can be concluded that the problem in using Edmodo is the internet network. This network constraint is a big obstacle in online learning. We often encounter many students who live in remote areas and have to find a place to get a good network connection to carry out the online learning process. Network constraints are what we often encounter in online learning problems. When the internet connection is not stable, it makes it difficult for them to implement Edmodo.

\subsubsection{Accessibility}

This is the result of the accessibility that the researcher found in the interview. Although the results of the questionnaire explained that Edmodo can be used anywhere and anytime, there are still problems that make Edmodo inefficient.

"Edmodo can only be accessed if you have a good connection"

\section{(QOR3.8)}

\section{The Suggestion of Edmodo}

The results of the questions regarding the suggestion of using Edmodo that were found on the interview are as follows: 
"Learning using Edmodo is very helpful. Because using Edmodo is very efficient for today's students, especially students today are inseparable from technology. So learning English using Edmodo is highly recommended for current and future students"

(R1.F)

"My advice is that if learning English uses Edmodo, the features are further improved so that they are more interesting and can be used for some time later, and given a translation feature to make it easier for users to understand the content in Edmodo"

(R2.F)

"My suggestion is that Edmodo should be further improved so that its use is easier and less confused, especially in the language section because the online learning application is also not only Edmodo, so if it is improved even better, hopefully many will use this Edmodo application to learn online"

(R5.F)

"My suggestion is to increase the choice of language in the application, because not all of them understand English" (R6.F)

"My advice is good because this application is also in accordance with current technology developments and is not difficult to use. This application is also very helpful for online learning in the future" (R7.F)

\section{DISCUSSION}

In the discussion, the researcher will explain students' perceptions of using Edmodo in online learning. These perceptions will be discussed in several indicators, namely: Usability, Accessibility, Helpfulness, Future use.

\subsection{Usability}

The results of the questionnaire showed that most respondents felt that the use of Edmodo was very helpful in the online learning process. The researcher considers that the respondent has a good experience using Edmodo. In the interview, there were various experiences of students using the Edmodo application. Most of the students in the interview stated that they used Edmodo because this application was good for online learning.

"I like using Edmodo, because the features in its use are not difficult, easy enough to understand, and selfexplanatory"

(R4.B)

"Edmodo is very helpful, because the Edmodo application is easy to understand so learning is not confused" (R3.C)

"I like online learning using Edmodo because it is not complicated and clearly understands the material with videos / material shared by lecturers, and features that are easy to understand and not confusing“

(R6.B)

From this indicator, it can be seen that all respondents in the interview session felt that Edmodo was easy to use in online learning. This is also supported by the results of the questionnaire obtained, there are $70 \%$ of respondents who answered that Edmodo is very helpful for them in implementing online learning. 25\% of students chose neutral and 5\% of students chose not to help. This can be indicated that the first response of the student felt that she really liked using Edmodo because it was easy to use and not confusing. Second, students answered Edmodo was very helpful because the features in Edmodo were very easy to understand. From the two responses, it can be concluded that students' perceptions of useability are good.

\subsection{Accessibility}

Accessibility is one of the factors that influence student perceptions. Based on a questionnaire of many students who gave positive responses about Edmodo, this was reinforced by their responses in interviews. They really like this application because access is very easy to reach and not complicated. Respondents felt that the features in Edmodo are easy to understand 
and Edmodo also helps respondents complete tasks well. In the interview session several respondents stated:

“...Edmodo's learning system is easy to understand."

(R1.C)

“...Edmodo is very easy to understand and also if there are assignments it can be easily used."

(R7.C)

"Learning is easier to understand via video, we can also ask our lecturers there " (R3.E)

From this indicator, it can be seen that students understand very easily the features contained in Edmodo. The first respondent felt that the learning system using Edmodo was easy to understand. The second respondent stated that Edmodo is very easy to understand and also very easy to do the task. The third respondent stated that Edmodo can send video material and make it easier for him to understand the material via video. From the results of the above interviews it can be indicated that the students' perceptions of accessibility gave excellent results.

\subsection{Helpfulness}

Based on this indicator, respondents feel that Edmodo is very helpful in the learning process. Many respondents gave good results. It can be seen from the results of the interviews.

"...Edmodo is also very good to use and effective for improving English learning skills"

(R6.C)

"Edmodo is a platform used to share material, ppt, video and more. Edmodo is also good to use in learning because it helps me do the assignments the teacher gives me when studying online like now"

(R6.A)

"I think it really helps, especially in doing assignments, to answer them quite easily, then we can also find out our value directly"

(R4.C)
From the responses above, it can be seen that some participants felt there were no difficulties and were very helpful in using Edmodo. The first answer given by the respondent shows that Edmodo is very good to use and it is also effective for improving English skills. Both respondents stated that Edmodo helps to share material in the form of files, ppt, video etc. Edmodo is also very helpful with online assignments. The three respondents stated that the respondents were very helpful, especially in doing their assignments and answering them was quite easy. But there is one student who feels confused about using Edmodo.

"...this is my first time trying Edmodo so I'm still a little confused about how to use it, especially since the language is only in English"

(R5.B)

Respondents felt that it was the first time using Edmodo and also the language contained in Edmodo is using English which makes respondents feel confused. But more students stated that Edmodo is very helpful in the online learning process. From some of the students' perceptual interview results, it can be concluded that almost all respondents did not experience difficulties. Based on the results of the questionnaire, $60 \%$ of respondents gave good results in using Edmodo. $35 \%$ of respondents answered neutral and $5 \%$ of respondents answered that they did not help. However, the results showed that almost all respondents gave satisfactory results.

\subsection{Future Use}

In this indicator discusses the feature use. Based on the results of the analysis of student perception data, respondents stated that they agreed to use Edmodo in the future. Students feel that Edmodo is easy to use and its features are not confusing, this can make students feel less complicated when doing online classes. This can be seen from the results of student interviews which state:

"...This application is also very helpful for online learning in the future" 
(R7.F)

"....and its use is not difficult, especially in doing assignments using Edmodo because it is very easy"

(R4.A)

"...Edmodo is like an intermediary place to help students learn as well as do assignments online and how to use it is quite easy"

(R5.A)

"...by using edmodo the process of learning and completing the task is simple, no need to open this link, just open the application, do the task you want to do lgsg, send, then complete the task"

(R3.B)

Based on the results of the questionnaire, $60 \%$ of respondents gave good results, respondents chose agree if Edmodo was used in the future. 35\% of respondents answered neutral and $5 \%$ of respondents chose disagree. From the results above, it can be indicated that respondents feel strongly agree that Edmodo is used as a learning medium in the future.

\section{CONCLUSION}

Edmodo is an internet-based learning platform to support the virtual classroom learning process where Edmodo provides features for sharing material, communicating with lecturer and doing assignments online. Edmodo has many essential benefits in it, such as can doing online classes with existing features, can share between users, can be done anywhere and anytime if there is an internet connection. Edmodo is one of the recommended ways to facilitate technology in online learning classroom.

In this study, respondents felt very helpful when using Edmodo as online learning. They feel that Edmodo is very easy to use, easy to understand features, they can discuss with other friends in the comment's column. Edmodo can also be accessed using the web www.Edmodo.com and you don't have to download an application on the App store. Edmodo is very easy for remote computers to access as long as the computer is connected to an internet connection. In Edmodo, there are several features that can be used by students. First, Parent Code is a class code that can be given to parents, so parents can also join the class to monitor their children in class. Second, Assignment is a service to be more effective and efficient in giving tigas to students. Third, Quiz can help teachers to be able to provide exam questions online. Fourth, these files and links help teachers to provide material in the form of document files, audio, video and others. From the existing features, teachers can communicate with each other through Edmodo.

The results of this study also show insights into how students apply Edmodo as a tool that helps in online learning. Edmodo is a great platform to use in a pandemic like this one. In addition, Edmodo can also make students interested in learning English because it is very easy to use. The use of Edmodo can also trigger students to learn more enthusiastically because, after carrying out the quiz, the teacher can immediately provide value and can make students feel satisfied.

Edmodo is also effective in using English classroom because most students state Edmodo can help online learning that can be done anywhere and anytime if there is an internet connection.

\section{ACKNOWLEDGMENT}

This study was supported by English Laboratory of Universitas Bandar Lampung. The authors wish to thank students of English Laboratory Universitas Bandar Lampung for their willingness to be our participants that make this study possible.

\section{Conflict of Interest: None}

\section{Source of Funding: None}

\section{REFERENCES}

1. Alebaikan, et al. (2010). Blended learning in Saudi universities: challenges and perspectives. Research in Learning Technology. Vol. 18, No. 1, 49-59 
Yanuar Dwi Prastyo et.al. Students' perception of the implementation of Edmodo learning platform in online learning.

2. BBC. (2020). Pendidikan anak: Hampir 10 juta anak 'berisiko putus sekolah permanen' akibat pandemi Covid-19, kata badan amal. $\mathrm{BBC}$

News. https://www.bbc.com/indonesia/majalah53385718. 13 Juli 2020.

3. Dewi, F. (2014).EDMODO: A Social Learning Platform for Blended Learning Class in Higher Education. Research in Education Technology: Pedagogy and Technology Journal. SEAMEOSEAMOLEC. Vol XI/No.2/2014

4. Giang \& Minh. (2014). Edmodo - A New and Effective Blended Learning Solution. Prosiding. 2014 International Conference. Ho Chi Minh City.
5. Miarso, Y. (2007). Menyemai Benih Teknologi Pendidikan: Vol. Edisi I Ce. Jakarta: Kencana Prenada Media Group.

6. Mirzon Daheri, Juliana, Deriwanto, A. D. A. (2020). Efektifitas Whatsapp Sebagai Media Belajar Daring. Jurnal Basicedu, 3(2), 524532.

Https://Doi.Org/10.31004/Basicedu.V4i4.44 5

How to cite this article: Yanuar Dwi Prastyo, Maratus Solihah. Students' perception of the implementation of Edmodo learning platform in online learning. International Journal of Research and Review. 2021; 8(12): 384-392. DOI: https://doi.org/10.52403/ijrr.20211247 